\section{Toby Emert}

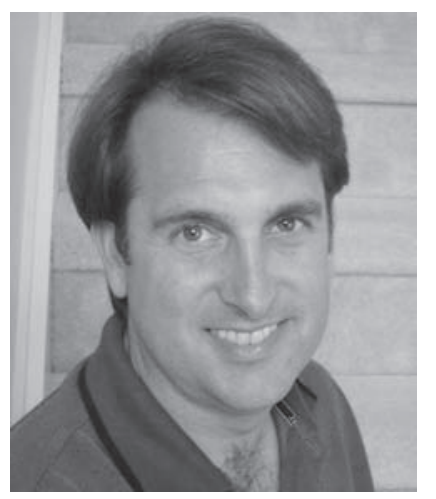

\title{
ZigZag to 'Zines:
}

\section{A Conversation with Ellen Wittlinger}

“I $\mathrm{t}$ took me a while to figure out that what suited me best was writing novels for young adults," Ellen Wittlinger, author of many critically acclaimed YA books, admits. A graduate of the prestigious creative writing program at the University of Iowa, Wittlinger has been a poet and a playwright, and she credits both genres for their strong influence on her fiction. She currently writes full-time from her home in a small town in Massachusetts, where she lives with her husband, an editor for the American Heritage Dictionary. "It's always helpful to have him around when I need the exact word," she quips.

Wittlinger possesses a particularly keen sense of character, inventing teenaged personas whose ways of managing in a world that confuses them seem both relevant and realistic. Her novels include, among others, Razzle, The Long Night of Leo and Bree, What's in a Name, ZigZag, Gracie's Girl, Sandpiper, and perhaps her best-known book, Hard Love, which won the Lambda Literary Award, was selected as a Michael L. Printz Honor Book, and received critical attention from the American Library Association, Booklist, and School Library Journal (Best Book of the Year).

Reviewers have called Wittlinger's characters articulate, emotionally in tune, and remarkably true. She does not hesitate to take on controversial, though realistic, subjects in her novels-romantic attractions of various sorts, the awkwardness of teen sex, situa- tions in which parents are distant and uninvolved, and even abduction-but she does so with great sensitivity, rendering characters that both challenge and delight readers. In doing so, she offers what some readers have called bittersweet portraits of adolescents struggling fiercely to establish emotional connections in an often unstable world.

"Young adults will love the wit and poignancy of these clever teens striving to discover who they are," JoAnn Carhart, writes in School Library Journal of Gio and Marisol, the protagonists in Hard Love, whose relationship is complicated by Gio's romantic attraction to Marisol, an out-of-the-closet lesbian. Chris Moning also notes Wittlinger's ability to write teenagers that are "deftly layered and textured, . . . uncommonly well-drawn" in a review for Children's Literature of Razzle, which was designated a YALSA Best Book for Young Adults and won the Patterson Prize for Books for Young People in 2002. Moning continues, "This novel shines where so many others fall short."

Realistic complexities are a trademark of Wittlinger's writing. "Deep-down, each character is filled with anxieties about identity but also with surprising resources," says Jane Kurtz in a review of What's in a Name, a series of ten dovetailed short stories which won the Massachusetts Book Award in Children's Literature. With the publication of her most recent novel, Sandpiper, Wittlinger has now written 
ten young adult novels, garnering more than seventy awards and special recognitions. Her capacity to tackle what are often considered controversial topics while maintaining the integrity of her characters' motivations continues to impress both critics and readers. "With gentle wisdom," Jane Halsall writes in School Library Journal, “Wittlinger's writing conveys a fundamental truth: life is a nonlinear journey."

I sat down to talk with Wittlinger at the 2004 ALAN Workshop in Indianapolis, Indiana. She had been invited as a speaker for two of the panel sessions, and after her talks, we found a quiet space in one of the conference breakout rooms to discuss the books she's written and the ones she's working on.

Emert: Though you've written several young adult novels, Hard Love is the book that appears to have gotten the most attention. The novel employs such an interesting format and the relationship is so interesting. Where did the idea for the novel come from?

Wittlinger: Well, the two strains in the book are perhaps what make it stand out: the idea of writing 'zines and the lesbian girl/straight guy angle. I'm not sure why I put them together. The 'zine idea developed because my daughter was fifteen at the time I began writing it, and she had a good friend who was making 'zines. I thought, "Oh, that would be a great thing to do in a book.” My daughter's friend happily gave me a box of 'zines she'd collected, and I sorted through them and picked the ones I really liked and wrote to those authors, asking how they got started. Not everybody answered, but a lot of kids did and they sent me more 'zines, or they gave me addresses of other 'zine writers. I've got a nice circle of kids whom I've talked to about 'zines. A 'zine is a way for kids to put both their art and their writing out in the world and let other kids see it, but it flies under the radar, so parents aren't necessarily going to see it. When I wrote Hard Love, I'd already published two YA novels, and I was thinking I wanted to write a book featuring a gay character. There had been other books with gay characters, but I wanted to write a book that was not about coming out. I wanted my character to be comfortable with being out, but still dealing with some of the effects since she's only seventeen. And that is where Marisol came in. I don't know exactly where she sprang from, but she sprang full-blown, probably from the first 'zine entry in the novel where she tells us who she is pretty bluntly. Once I had her voice, she was just really right there.

Emert: How did you come up with the names Marisol and Gio?

Wittlinger: My niece used to have a best friend named Marisol, and I never met her but as soon as I heard that name, I knew I had to use it. I loved the name so much, and I looked up what it meant- "bitter sun," which seemed perfect for her. Names are very important to me when I write. I was talking about this idea with Garret FreymannWeyr recently. We agreed that once we have the right name, we can begin to see the character, and he or she immediately becomes alive. I'm not quite sure how I came up with Gio; I guess I wanted him to be John because it seemed like the most common name. He began as a blank slate though I knew I wanted him to be named after his father. Eventually he renames himself the more exotic "Giovanni." I love the naming process. Naming something is such fun. I should get more animals so I can name them.

Emert: When I was a kid I loved naming animals. I grew up on a farm so we had plenty of animals to name.

Wittlinger: I should live on a farm.

Emert: One of the teachers I talked with about Hard Love said that when she discovered it and read it and started suggesting it to her students, the girls in her class immediately started reading it and passing it around. She can't keep it on the shelf. But she's having a difficult time getting the boys to read the book, even though it has a male protagonist. Any response to that?

Wittlinger: Well, you know, I'm not surprised because it is sometimes hard to get boys to read novels, and if they perceive the book is about love, perhaps that's the problem. But I get quite a few 
letters from boys who have read Hard Love and really responded to it. Some of them are gay, but the majority of them probably aren't. The first publisher I sent the book to rejected it because it had a male protagonist; they said not enough boys read books and girls won't read about boys. Well, of course that was not true. But I don't know how you interest boys in reading. My own son doesn't read that much.

Emert: It's a tough professional issue for us as teachers.

Wittlinger: It is. I was a children's librarian for three years in my local town. I found myself making lists of books for boys even though I didn't like the idea of segregating the books according to gender. You entice some, but it's hard to break their shell. They think there is something "girly" about reading, or they'd rather be doing more active things. I can't pinpoint the problem.

Emert: It is an interesting question for me because your book has a nontraditional relationship, well, in a lot of ways. Alex Sanchez, who wrote Rainbow Boys and Rainbow High, says that high school girls love his books and all of the main characters are males in nontraditional relationships. They're gay characters, of course.

Wittlinger: I love Rainbow Boys.

Emert: I'm wondering if there's something about the fact that there is the gay/lesbian character in the book that makes it problematic for male readers.

Wittlinger: Maybe if it were a sports book, the lesbian character would be okay, but the fact that it's about relationships, about feelings makes it more difficult. I mean I actually think that a lot of boys, if they read it, would like it. It's just that there is a barrier to cross to get them to read it.

Emert: The male college students I have in my education courses have loved Hard Love and Rainbow Boys. So, maybe that's it ... getting them started. I have a related question. I've noticed about at least three of your novels, Razzle, Leo and
Bree, and Hard Love, that there is a major male character who seems to be honing or refining his identity through his relationship with a female character. Would you say that's true?

Wittlinger: I think that is absolutely true.

Emert: Is that purposeful?

Wittlinger: I don't know that I set out consciously to do that when I started writing, but I think in almost all my books the main character is involved with a secondary character of the other gender who is almost as weighty as the main character. I do think that has become purposeful. I did it, liked it, and now it's purposeful. For one thing, I want both girls and boys to read the books, and I'm trying to fight the stereotype that relationship books are only for girls. Also, I think that in your teens a lot of what you're learning is how to relate to people: "Do they like me? Do I like them?" In puberty you are really trying to pick up the cues. Perhaps that's the most important thing going on in those years. You're dealing with your own sexuality and with other people's. You're constantly thinking, "How do I relate to them and who they are as a sexual person?" So, I think it is really important to explore those ideas, and I do try to do that. You are not wrong; that's become a thread through my books.

Emert: So what influence has winning the Lambda Literary Award for Hard Love had on your career?

Wittlinger: It is hard to know. I mean that book certainly has done very well, but it also was an honor book for the Printz Award. So, I don't know what to base it on. I do go into gay bookstores now and then to see if it's there. I would say more often than not it is. When I get letters from kids, the ones I like best are from straight kids, and they sometimes say things like, "I was really scared of homosexuals before I read Hard Love" or "I just didn't understand what it meant to be gay until I read your book." One girl wrote that after she "met Marisol," which I loved-the idea of meeting a character from the book, she understood that Marisol was just a person like she was. I loved that letter. 
Emert: What a special response to the character and to the story you helped her tell.

Wittlinger: It was great.

Emert: What about the physical formatting of the book, with the 'zine pages? Did you have some say in that?

Wittlinger: I just asked if pages could be done in 'zine style and they ran with it. I didn't have to beg. Simon and Schuster did a great job with the design of the book. They ended up getting somebody who had designed 'zines to do the cover and, ultimately, that cover won an award.

Emert: I didn’t realize that.

Wittlinger: The art director really took to the idea of the alternative layout. They've also been great with the formatting of my new book, Heart on My Sleeve, which is composed entirely of emails, I.M.'s, and letters.

Emert: What was the process of getting the book published like?

Wittlinger: It went to a couple of places before Simon and Schuster. Somebody didn't want it because it had a male protagonist. Another editor liked it, but I think was a little scared of it-not scared to publish it, but scared that it wouldn't sell very well because of the topic. And at that point I got an agent, and my agent said, "I'm sending this to David Gale.”

Emert: So, he was your editor for it?

Wittlinger: Yeah, and he’s been my editor ever since.

Emert: So, let's talk a little about the controversial nature of the book. Obviously when you were writing it and sending it out, you had to know that some flags might go up for people.

Wittlinger: I really didn't think the subject matter of the book would stop it from being published. I thought somebody would want to publish it, though I knew it might not be the first person who read it. It just seemed like the right time for a book that dealt with gay characters but did not focus on coming out. I felt like we could go in another direction now: we could have a character be gay, but not have that be the whole story. I think half my books have gay characters in them-sometimes just in the background, sometimes as a main character-and I think that reflects the world we live in. It's time that kids figure this out and learn to deal with it. Reading a book like Hard Love offers some kids a very comfortable way to do that. They meet these characters, and the characters don't seem so frightening. So maybe if somebody in their school comes out to them or the school starts a gay-straight alliance, it's not such a huge, weird thing. Maybe they'll be able to deal with it more easily.

Emert: Well, I think that Marisol is a nice character to meet. She's sort of lovely and non-threatening. People seem to sometimes be threatened by gay and lesbian characters.

wittlinger: Yeah, I think that's true.

Emert: And the struggle that Gio is having with his feelings about her probably makes a lot of sense to kids.

Wittlinger: I hope so. A lot of kids do write and ask why he didn't change her-why it didn't have a happy ending with her becoming straight. I try to respond to that as clearly as I can.

Emert: What do you say?

Wittlinger: Well, I say that's kind of wishful thinking - sort of a magic ending-and that's not what would really happen, unless Marisol really wasn't a lesbian. But this character really is and she understands that. I like to play with the point in relations between two people where they're not in love on a sexual basis - they aren't going to be life-long partners-and yet there is love between them, though we don't usually call it love. It often happens between gay men and straight women. You don't too often see the opposite, and that's 
why I wanted to do the opposite thing with these two characters. I wanted to keep that: the close relationship they had that was based on something other than sexuality.

Emert: I think that's part of the brilliance of the book-that relationship-because it does turn upside down what we think of as a stereotypical relationship between a gay man and a straight woman. This book flips that dynamic. I used the word non-threatening because in our culture I think men, in particular, tend to be threatened by the notion of lesbians.

Wittlinger: I think that is true, and maybe that's why some boys are sort of put off by the book.

Emert: Maybe if they knew what it is about and if they read the first page, they would get into it.

Wittlinger: Yeah, and some boys have. I am so thrilled when I get letters from boys; right away they tell me if they are gay or straight. Then they go into whatever the problem with their relationship is: "I have this girlfriend or boyfriend, and this happened or that happened." It's great. I love that they're telling me their whole love story.

Emert: Do you go into schools much?

Wittlinger: I go some. They don't want me to talk about Hard Love though; I'm usually invited to middle schools. High schools don't tend to invite authors. There are one or two of my books that middle schools are willing to talk about, and the rest they won't. Hard Love is off limits. It's too bad. That's the one that's the most fun to talk about; any of the edgy ones are more fun to talk about. I would love to go somewhere and discuss Leo and Bree, but nobody would let me do that.

Emert: So if you could go into a class of 11th and 12th graders, for example, and talk with students, what would you want to say about Hard Love?

Wittlinger: What would I say to them? Maybe I'd ask them if they know or have any gay friends. I'd ask if this portrayal of gay characters rings true. I guess
I'd like to just shake them up a little, maybe shock them a little bit. Get them to look around and not be quite as narrow. Kids often just see what they want to see, what's in their own little rooms and their own line of vision. I like to knock those walls down if I can and get them to look around, to be open-minded and open-hearted. I feel like you have to start on the inside of a character and figure out who he or she is as a person first and then see him or her as gay or Black or male or whatever. People have layers; if you think of the inner layer first, everybody has things in common. I try to start there and build out. I'd want to talk with them about that idea.

Emert: How did you come up with the title, Hard Love?

Wittlinger: Well, I just stole it from the song "Hard Love." I didn't have a title for the book until I was well into writing it. The working title was Escape Velocity, but I wasn't crazy about that. I was looking for a song for Diana, the Cape Cod girl who's the singer. I wanted her to be singing a song at the group get-together that would somehow resonate for Gio. I'm kind of a folk music fan, so I went though all of my folk stuff and then all of my daughter's folk stuff. Nothing was really working until I pulled out this old Bob Franke album that I had and put it on. I was listening to the words to "Hard Love," and it started keying into all these places in the book. The song seemed to be written for the book-it was amazing. So, I actually called him and got the rights so that I could put the whole song in the book and then use the title for the title of the book. That was serendipity-it just happened.

Emert: Do you ever think about the possibility of writing sequels to your books? Would you consider doing a sequel to this one?

Wittlinger: I don't know. The question I get asked most often is about writing sequels. I have been reluctant. I feel like the chances of the sequel not being as good as the original are high. The characters and the idea are so focused in that first book. I'm always afraid if I try to extend it, it's just not going to work. I guess if I did do a sequel to Hard 
Love $_{2}$ it would be Marisol's story. Maybe take it a little further, but the problem with doing that is that she's already out of high school. Publishers don't really want to publish a YA novel about people who are already out of high school. So, I'm not sure and I've kind of already told her story. I don't know that I want to go back and tell it again. I wouldn't mind having her show up in a book again though.

Emert: What kind of adults do you think Gio and Marisol grow up to be?

Wittlinger: Well, she is obviously going places. I think she's going to end up being a playwright. She really can get into people, she's good, deep. She's going to go to New York, and she's going to find love. She can touch people. She'll be great. I think Gio has a tougher road ahead of him. He's got to deal with his dad. He's done some dealing. He's gotten his mother to open up a bit. I think that's going to be a great thing for him. I think his father's never going to get it; it's not going to work. His father's going to be a source of pain for him, but I think the writing's going to help. I don't know that he'll be a writer when he grows up, but I think he's going to find somebody to love down the line and he's going to be okay. I think it's going to be a tough road for him. He's got work to do.

Emert: It's kind of fun to speculate about them.

Wittlinger: It really is.

Emert: What's coming up for you? What controversial books are you working on?

Wittlinger: The book that is coming out next is called Sandpiper. It's about a girl who is a sophomore in high school. She has been giving oral sex to boys since she was in the 8th grade, and this has kind of become who she is. She has lost her closest girlfriends and has had a series of very quick relationships with guys that don't go anywhere. The guys have gone from being pretty nice guys to being real jerks. So, I have a feeling this book is probably not going to make everybody's list.

Emert: Have you written it already?
Wittlinger: Yes, it's coming out in Summer 2005. The one following it is about death and God and belief. The one that I'm chomping at the bit now to get going on is about a transgendered, female to male, character. I've got this great twenty-four year old guy who is helping me with it-answering every possible question I could ask. I can't wait to get started on it. I think it's going to be funny. It's not going to be heavy, deep, and tragic. I'm really psyched to get into it.

Emert: I don't remember any YA stories with transgendered characters with the exception of Francesca Lia Block's, perhaps.

Wittlinger: Well, Luna by Julie Ann Peters, has a main character who is male to female transgendered. Again, that book deals with the process of acceptance. I think that's got to be done too, but that's not what I want to write. I think it's easier to show who the person is rather than what the problem is. I come at it from a different angle: not here's this big problem that's inundating this person, but rather here's this person and he or she is dealing with this situation.

Emert: Normalizing it somehow.

Wittlinger: Yeah, that's right normalizing. I really think the issue of transexuality is going to travel a similar route to the one homosexuality has. People are going to become more aware of it and twenty years from now they'll be saying, "Oh, yeah, my cousin or my niece is transgendered." It won't be such a big deal anymore. It's going to become normalized, and I want to be part of that process.

Emert: This may not be a fair question. I'm wondering in light of the moral values rhetoric we hear around us, the kinds of topics you're writing about, the kinds of issues you're bringing to the fore are the kinds of issues that some people will continue to take exception to. Any response to that?

Wittlinger: I don't think you can let that get in your way. There will always be people who believe that having moral values means never talking about anything controversial. But you have to write what 
interests you, what you can get behind and feel good about. There's always going to be a market for it even if it's not in every school and every library. There are still plenty of people who want to have conversations about the truth. There has to be the first book, so there can be the second book, and so on down the line.

Emert: Well, thanks for writing some of the first ones.

Wittlinger: Thanks for asking me to talk about them. This has been really fun.

Dr. Toby Emert currently teaches in the School of Education at the University of Kentucky, where he directs the English Education program. He also teaches in the Creative Arts in Learning Graduate Program for Lesley
University, traveling around the country to work with teachers to integrate drama into their classrooms. Dr. Emert began his teaching career at Bayside Middle School in Virginia Beach, Virginia, where he taught Seventh Grade English and Drama I, and has since worked for the University of Texas, Longwood College, the University of Virginia, and Kennesaw State University.

\section{Works Cited}

Carhart, Jo-Ann. Rev. of Hard Love by Ellen Wittlinger. School Library Journal Dec. 2001: 77-78.

Halsall, Jane. Rev. of Zigzag by Ellen Wittlinger. School Library Journal Aug. 2003: 169.

Kurtz, Jane. Rev. of What's In a Name? by Ellen Wittlinger. The Five Ow/s Sept. 2000: 20.

Moning, Christopher. Rev. of Razzle by Ellen Wittlinger. Children's Literature Oct. 2001: 17. Children's Literature Comprehensive Database. 23 July $2005<$ http:// clcd.odyssi.com/cgi-bin/member/search>. 


\title{
Review of Sandpiper by Ellen Wittlinger, Simon \& Schuster, ISBN: 0689868022, 240 pages. \$16.95
}

\author{
By Toby Emert
}

S andpiper Hollow Ragsdale isn't particularly fond of the name her parents have given her or of the name she has made for herself as the local high school "blowjob" queen. At fifteen, she has already been out with a long list of guys, none of whom really interested her, but all of whom made her feel desired and excited-at first. Things always ended up the same way though, with Sandpiper feeling anonymous- "not even there anymore"and with her abruptly ending the relationship. It's during a heated argument about the break-up with Andrew, her latest "boyfriend," that she encounters a mysterious character she calls the "Walker." A young man who appears to spend all of his time wandering about town, the "Walker" passes by as Andrew threatens Sandpiper, stops, and ushers her out of the situation. She develops an immediate fascination and a bit of a crush-yet another complication in her already complicated life.

Ellen Wittlinger's protagonist in her latest novel, titled simply Sandpiper, is no ordinary heroine, but she is the kind of fifteen-year-old many young adult readers will find interesting and want to understand. Piper, as she is ultimately dubbed by the "Walker," has more to be concerned about than just her reputation. One of the boys she hooked up with has become a menace, her mother is remarrying in a matter of three weeks, her too-perfect stepsister, whom she has never met, is arriving from the West Coast, and her father does not know how to talk to her now that she has become a teenager. To cope, Piper hooks up with boys and writes poems. In fact, each chapter of the novel includes one of Piper's poems as its last page-a technique that is both clever, revealing, and perfectly adolescent: "Her perfect shell covers / a churning heart, a hollow hell," Piper writes in "Duckfoot."

The novel is fast-paced, with a series of escalating conflicts that tend to touch each character in some way. This is perhaps one of the novel's great strengths: it delivers a family of characters who, each in his or her own way, is struggling with the idea of redemption and, ultimately, acceptance, and who must ultimately find ways to depend on each other to work out that redemption. Piper's secret sexual activity is no more transgressive than the "Walker's" mysterious background or her father's penchant for flirtatious dalliances with younger women. Though the story of the novel belongs clearly to Piper, Wittlinger does a fine job of incorporating a rather full cast of believable flawed characters, whose motivations seem realistic and very human.

As in her other novels, Wittlinger chooses to write about adolescents who are searching for a place in the world and who make difficult choices in their efforts to find it. Sandpiper Hollow Ragsdale discovers not only a name that is more her own, but begins to forge an identity that, in effect, saves her. Wittlinger deftly makes us want to follow along as she attempts to figure out how to do that. In Piper, she gives us a character easy to root for, precisely because of Piper's transparency: we are allowed to witness her internal struggles and we are both interested and hopeful. "In a dark time I begin to see," Piper writes in one of the last poems in the novel. What she sees is not uncomplicated. Wittlinger is too smart a writer to wrap things up too neatly. Piper knows the world is dangerous, but she also comes to understand that she-and others-can make choices that will allow for some safe passage. 